\title{
A thrombocytopenia ritka oka: Gaucher-kór
}

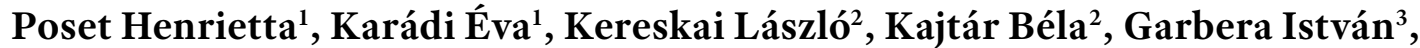 \\ Egyed Miklós ${ }^{1 @}$
}

\author{
${ }^{1}$ Somogy Megyei Kaposi Mór Oktató Kórház, Haematológia Osztály, Kaposvár \\ ${ }^{2}$ Pécsi Tudományegyetem Klinikai Központ, Pathológiai Intézet I. Szövettan és Cytológia, Pécs \\ ${ }^{3}$ Somogy Megyei Kaposi Mór Oktató Kórház, Dr. Baka József Diagnosztikai, \\ Onkoradiológiai, Kutatási és Oktatási Központ, Kaposvár
}

\begin{abstract}
A Gaucher-kór a leggyakrabban előforduló lizoszómális tárolási betegség, amiért a $\beta$-glucocerebrosidase enzim elégtelen müködése a felelős. A betegség ritka, incidenciája 1/60 000, az askenázi zsidók körében 1/1000 (850). Hazánkban jelentősen aluldiagnosztizált, mivel korábbi adatok szerint 34 Gaucher-kóros beteg ismert. Főbb tünetei: fáradékonyság, vérzés, anaemia, gyakori infekciók, csontfájdalom, pathológiás csonttörések, neuropáthiás fájdalom, splenomegalia és a növekedés elmaradása. Egy 34 éves férfit splenomegalia és thrombocytopenia miatt vizsgáltuk. A crista biopszia során tárolási betegségre jellemző csontvelői macrophagszaporulat mutatkozott. A száraz vércseppteszt Gaucher-kór pozitivitást igazolt. Az öröklődő betegség miatt végzett családkutatás során a beteg húgánál szintén igazolódott a veleszületett enzimzavar. A diagnózis felállítása óta mindketten enzimszubsztitúcióban részesülnek, mely mellett betegségük jól kontrollált. Esetünkkel a thrombocytopenia hátterében előforduló ritkább, de jól kezelhető betegségre szeretnénk felhívni a figyelmet.
\end{abstract}

Kulcsszavak: Gaucher-kór, anaemia, splenomegalia, crista biopszia, száraz vércseppteszt, thrombocytopenia

\section{A rare cause of thrompocytopenia: Gaucher disease}

Gaucher disease is the most common lysosomal storage disorder caused by low activity of the $\beta$-glucocerebroside enzyme. The incidence of this rare disease is 1 of 60000 people, in the Ashkenazi Jewish population this number is $1 / 1000$ (850). In Hungary, Gaucher disease is significantly underdiagnosed, since the number of known cases of this disorder is 34. Main symptoms: fatigability, bleeding, anaemia, frequent infection, bone pain, pathological bone fracture, neuropathic pain, splenomegaly, stunted growth. A 34-years-old man was examined due to splenomegaly and thrombocytopenia. The crista biopsy indicated increased number of medullary macrophage, which refers to storage disorder. Dried blood spot test demonstrated low $\beta$-glucocerebrosidase activity. The screening of the close family, given the hereditary nature of the disease, showed that the patient's younger sister also has enzyme dysfunction. After the diagnosis both of them received enzyme substitution therapy, which controls their symptoms well. With this case we would like to draw the attention to this rare but well-controllable disease, which can lay behind thrombocytopenia.

Keywords: Gaucher disease, anaemia, splenomegaly, crista biopsy, dried blood spot test, thrombocytopenia

(Beérkezett: 2019. július 16.; elfogadva: 2019. szeptember 26.)

A Gaucher-kór a leggyakrabban előforduló hereditaer lysosomalis tárolási betegség, melynek hátterében a $\beta$-glucocerebrosidase nevü enzim hiánya áll, ennek mérésén alapul a diagnózis is. A betegség autoszomális recesszív öröklődésű (GBA gén, I. kromoszóma housekeeping gén defektusa) [1]. A betegséget első leírójáról a francia bőrgyógyász és patológus Phillipe Gaucher-ról nevezték el, aki 1882-ben írta le egy 32 éves nő esete kapcsán [2].

\footnotetext{
@ Levelezési cím: Dr. Egyed Miklós, Somogy Megyei Kaposi Mór Oktató Kórház, Haematológia Osztály, Kaposvár; E-mail: dregyedmiklos@yahoo.com
} 
A sectio során a fiatal betegnél jelentősen megnagyobbodott lépet talált, a szövettani vizsgálattal szokatlanul nagy sejteket észlelt. Az esetet a lép malignus epitheliomájaként írta le. A betegség hátterében lévő lysosomalis savi $\beta$-glucocerebrosidase defektusát 1965-ben azonosította Roscoe Brady [2, 3]. A glucocerebrosidase a sejtfal felépítésében szerepet játszó glucocerebrosid lebontásában (fehér- és vörösvérsejtek) részt vevő enzim, melynek defektusa esetén a lebontás nem valósul meg, a köztes bomlástermékek a makrofágokban akkumulálódnak, melyek mind a parenchymás szervekben, mind a csontvelőben megtalálhatóak lesznek. Ez lesz az oka az organomegaliának, valamint a thrombocytopaeniának, gyermekekben a csöves csontos metaphysisében okozott károsodás miatt a növekedés elmaradásának, és a csontdeformitásoknak, illetve - igaz, ritka esetekben - bélrendszeri panaszoknak is. A ritka betegség incidenciája világszerte 1/60000, askenázi zsidók körében ez 1/1000 (850). Fő tünetei: fáradékonyság, vérzékenység, anaemia, splenomegalia, gyakori infekciók, csontfájdalom, pathológiás csonttörések, neuropáthia, növekedés elmaradása [3]. A Gaucher-kór a klinikai megjelenés szempontjából három fö fenotípusú csoportba osztható. A betegek döntő hányada (95\%) az 1-es típusú, nem neuropáthiás formába tartozik (GDI), amit a visceralis és a vázrendszert érintő tünetek jellemeznek. A 2-es típusú, akut neuropáthiás

1. táblázat. A férfi beteg laboreredményei

\begin{tabular}{lcc}
\hline & $\begin{array}{c}\text { Kiindulási vérkép } \\
\text { 2017. 07.24. }\end{array}$ & Egység \\
\hline Fehérvérsejt & 4,12 & $\mathrm{G} / \mathrm{l}$ \\
Vörösvérsejt & 4,76 & $\mathrm{~T} / \mathrm{l}$ \\
Hemoglobin & 129 & $\mathrm{~g} / \mathrm{l}$ \\
Hematokrit & 39,6 & $\%$ \\
MCV & 83 & $\mathrm{fl}$ \\
MCH & 27 & $\mathrm{pg}$ \\
Thrombocyta & 95 & $\mathrm{G} / \mathrm{l}$ \\
Reticulocyta & 95,20 & $\mathrm{G} / \mathrm{l}$ \\
CRP & 2 & $\mathrm{mg} / 1$ \\
Ferritin & 1545 & $\mu \mathrm{g} / \mathrm{l}$ \\
\hline
\end{tabular}

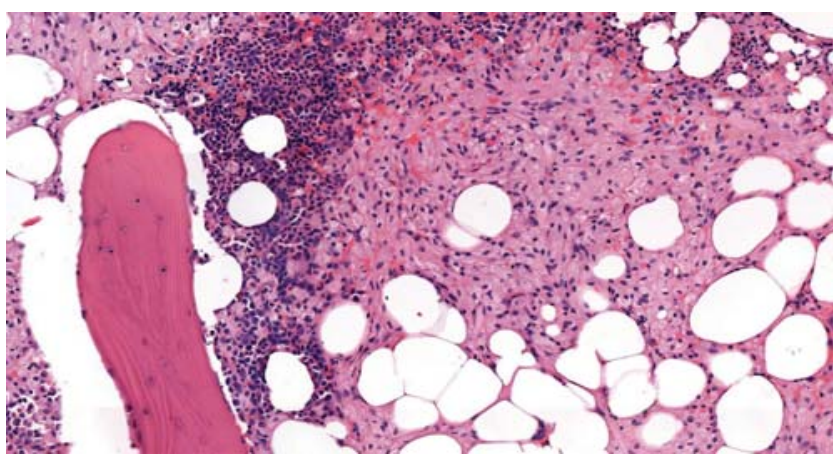

2. ábra. A csontvelő hematoxilin-eozin festése; „habos macrophagok” megjelenése

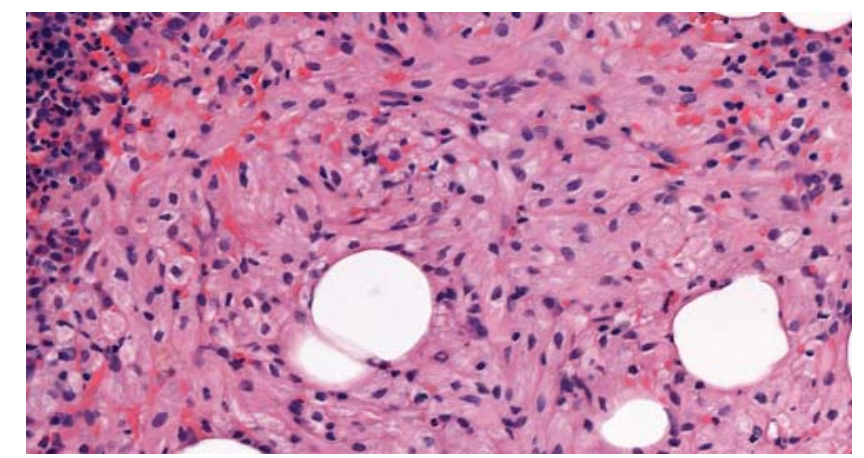

forma (GD2), ritka, csecsemókorban jelentkezik, gyorsan progrediáló, elsősorban agytörzsi múködészavarra utaló tünetek képében. A 3-as típusú, krónikus neuropáthiás forma (GD3), ritka, késői gyermekkorban vagy felnőttkorban fordul elő. A visceralis tünetekhez változatos neurológiai tünetek társulhatnak [4].

Ma két fő terápiás lehetőségünk van. ERT (enzyme replecament treatment), mely ténylegesen az enzimpótló kezelés, továbbá a SRT (substrate reduction therapy), mely csökkenti a szervezet által termelt glucocerebrosid mennyiségét.

Egy 34 éves férfi esetét mutatjuk be, akit pancytopenia, jelentős hepato- és splenomegalia miatt vizsgáltunk. Laboreredményeiben mérsékelt hypochrom anaemia, thrombocytopenia, leukopenia és hyperferritinaemia mutatkozott (1. táblázat).

Kvalitatív vérképében szignifikáns eltérés nem volt. Hasi ultrahangvizsgálat kapcsán multiplex splenicus gócokat láttak. A hasi CT-jén enyhe hepatomegalia, kifejezett splenomegalia, multiplex splenicus térfoglalás ábrázoló$\operatorname{dott}$ (1. ábra).

A lépgócok hátterében felmerült endocarditist transoesophagialis echocardiographiaval kizártuk. Lymphoproliferativ betegség gyanúja miatt crista biopsziát végeztünk. A 12 csontvelőürnyi mintában kb. 35\%-ban hypercellularis haemopoetikus zónák voltak láthatóak, kiérő granulo-

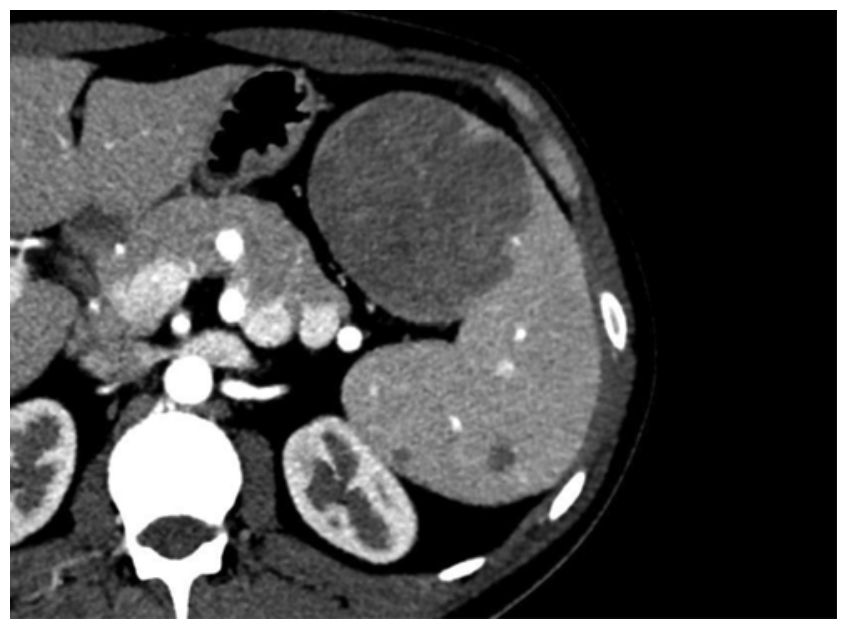

1. ábra. hasi CT-felvétel 

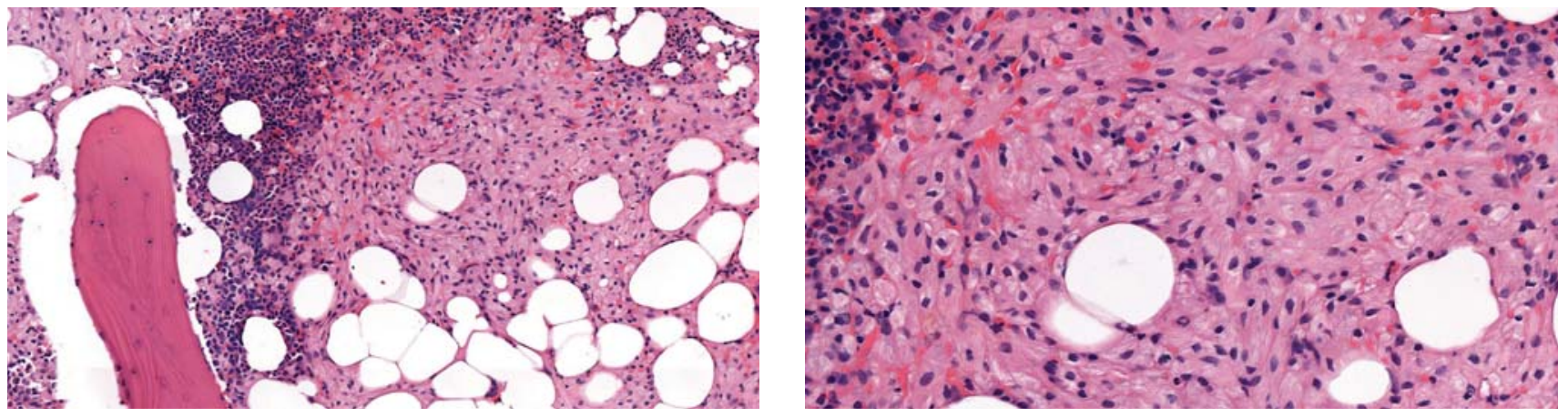

3. ábra. A csontvelő CD 68 festése (macrophagmarker)

2. táblázat. Specifikus laborvizsgálatok

\begin{tabular}{lccc}
\hline & Eredmény & Egység & Referenciatartomány \\
\hline Lyso-GL-1 & 749,1 & $\mathrm{ng} / \mathrm{ml}$ & $0,0-14,0$ \\
$\beta$-glucocerebrosidase & 0,3 & $\mu \mathrm{mol} / \mathrm{l} / \mathrm{h}$ & $>2,5$ \\
acid-sphingomyelinase & 4,7 & $\mu \mathrm{mol} / \mathrm{l} / \mathrm{h}$ & $>0,9$ \\
\hline
\end{tabular}

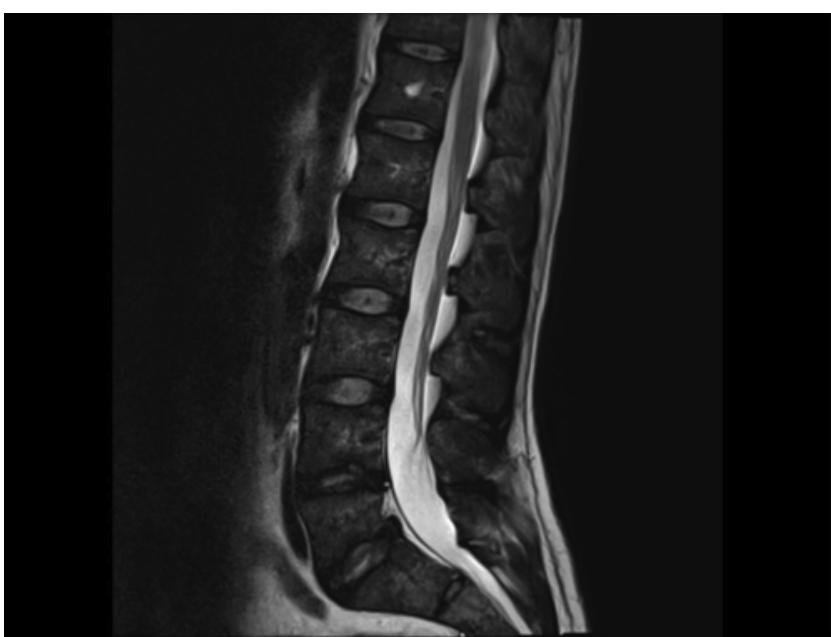

4. ábra. 1. beteg lumbalis gerinc-MRI: csigolyatestekben foltosan alacsony jelintenzitások

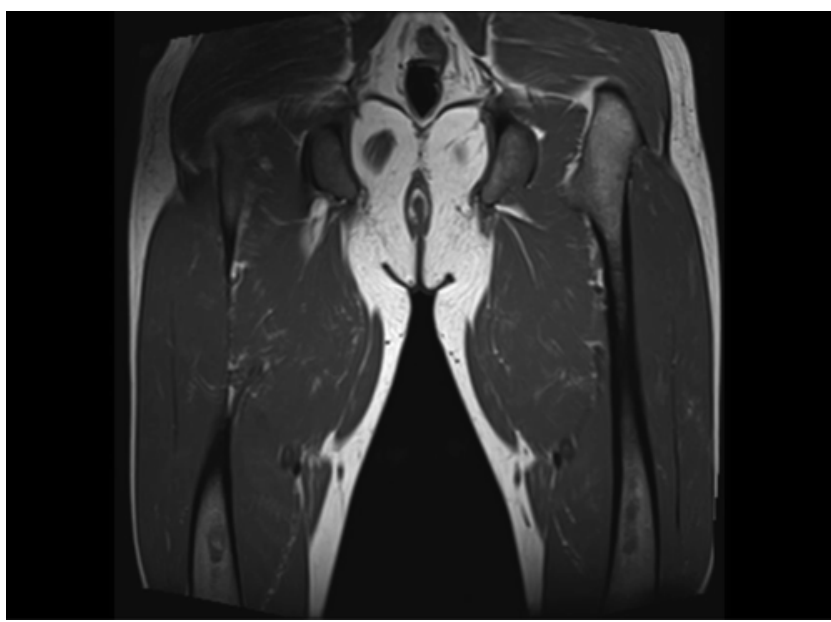

5. ábra. 1. beteg comb-MRI: Erlenmayer-lombik deformitás poesissel, erythropoesissel, megakaryocytákkal. Elsősorban a velőürök centrumában, máshol csaknem komplett velőűrnyi kiterjedésben mezőszerű jelleggel, széles, világos citoplazmájú, ovoid magvú macrophag jellegü sejtek infiltrációja volt látható (2. ábra). Az infiltráló sejtek CD 68-pozitívnak mutatkoztak (3. ábra). Tárolási betegségre jellemző csontvelői „habos macrophag” szaporulat, Gaucher-kór valószínűsége merült fel. Karyotipizálás kapcsán klonális eltérés nem volt igazolható.

Száraz vércseppteszt csökkent enzimaktivitást mutatott elősegítve a Gaucher-kór diagnózisát. A specifikus Lyso-GL-1 biomarkerszintje jelentősen emelkedett, a glucocerebrosidase enzim szintje nagyon alacsony volt (2. táblázat).

A diagnózis megerősítéséhez szükséges molekuláris genetikai teszt homozygota p. N409S-mutációt igazolt. A visceralis és csont érintettség megítélésére MR-vizsgá-

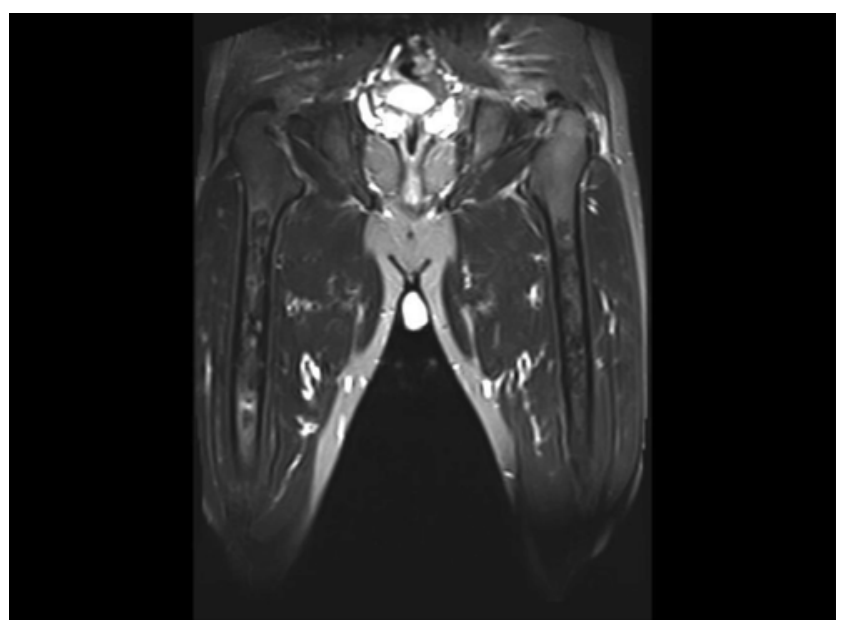

6. ábra. 1. beteg comb-MRI: foltosan alacsony jelintenzitású területek 
3. táblázat. A nőtestvér laborértékei

\begin{tabular}{lcc}
\hline & $\begin{array}{c}\text { Kiindulási vérkép } \\
\text { 2018. 04. 11. }\end{array}$ & Egység \\
\hline Fehérvérsejt & 5,03 & $\mathrm{G} / \mathrm{l}$ \\
Vörösvérsejt & 4,59 & $\mathrm{~T} / \mathrm{l}$ \\
Hemoglobin & 132 & $\mathrm{~g} / \mathrm{l}$ \\
Hematokrit & 40 & $\%$ \\
MCV & 87,1 & $\mathrm{fl}$ \\
MCH & 29 & $\mathrm{pg}$ \\
Thrombocyta & 75 & $\mathrm{G} / \mathrm{l}$ \\
$\mathrm{CRP}$ & $>1,0$ & $\mathrm{mg} / \mathrm{l}$ \\
Ferritin & $403,7(n=150$-ig $)$ & $\mu \mathrm{g} / \mathrm{l}$ \\
\hline
\end{tabular}

latok készültek. A Lumbalis gerinc- és comb-MRI mérsékelt fokú Erlenmayer-lombik deformitást mutatott. A csigolyatestekben és a femurban foltosan alacsony jelintenzitások voltak, amelyek Gaucher-kór részjelenségének feleltek meg. Hasi MRI-n hepatomegalia és splenomegalia ábrázolódott egy kifejezett gaucheromával.

A beteg klinikuma és vizsgálati eredményei alapján Gaucher-kórt (1-es típusú nem neuropáthiás forma-GD1) állapítottunk meg. A betegség autoszómális recesszív öröklődésére való tekintettel családszűrést végeztük. Anyai nagyapja fiatalon hirtelen hunyt el; a halál oka ismeretlen maradt. 36 éves férfitestvére nem volt érintett (negatív fizikális status, normál vérkép- és enzimaktivitás). A beteg 28 éves húgánál splenomegaliát, thrombocytopeniát észleltünk (3. táblázat), és a száraz vércseppteszt szintén csökkent $\beta$-glukocerebrozidáz enzimaktivitást igazolt. A specifikus Lyso-GL-1 biomarkerszintje itt is jelentősen emelkedett (4. táblázat). A molekuláris

4. táblázat. A nőtestvér specifikus laborvizsgálatai

\begin{tabular}{lccc}
\hline & Eredmény & Egység & Referenciatartomány \\
\hline Lyso-GL-1 & 852,0 & $\mathrm{ng} / \mathrm{ml}$ & $0,0-14,0$ \\
$\beta$-glucocerebrosidase & 0,5 & $\mu \mathrm{mol} / \mathrm{l} / \mathrm{h}$ & $>2,5$ \\
acid-sphingomyelinase & 3,1 & $\mu \mathrm{mol} / \mathrm{l} / \mathrm{h}$ & $>0,9$ \\
\hline
\end{tabular}

genetikai teszt nála is homozygota p. N409S-mutációt igazolt.

A testvérpárnál kéthetente adott $60 \mathrm{U} / \mathrm{kg}$ dózisú parenteralis imiglucerase kezelést kezdtünk. A hathónapos kontrollvizsgálat során a hepatosplenomegalia jelentős csökkenését és a csonteltérések regresszióját észleltük. A betegek anaemiája megszünt, thrombocytaszámuk normalizálódott.

Magyarországon korábbi adatok szerint 34 a felismert Gaucher-kóros betegek száma [1]. A várható prevalenciával szemben a betegség jelentősen aluldiagnosztizált annak ellenére, hogy Magyarországon újszülöttkorban a legtöbb gyermeket már szürik e ritka betegségre, valamint folyamatos konzultációs lehetőség is rendelkezésre áll telefonon és e-mail-ben (telefon: +36 30572 7668; e-mail: orvos@gaucherkor.hu). Felismerése fontos lenne, hiszen lényegében oki kezelése lehetséges, és a betegek részére
Európában egyedülállóan ingyenesen biztosított. A thrombocytopenia ritka oka tárolási betegség (köztük Gaucher-kór) is lehet. A differenciáldiagnosztika során különösen splenomegaliaval társult esetekben fel kell, hogy merüljön a lysosomalis tárolási betegség gyanúja is.

\section{Irodalom}

[1] Simon G, Erdős M, Maródi L, Tóth J. Gaucher disease: The importance of early diagnosis and therapy. Orvosi Hetilap 2008; 149(16): 743-750.

[2] Grabowski GA. Gaucher disease and other storage disorders. ASH Education Program Book 2012; 2012(1): 13-18.

[3] Brúgós B. Gaucher kór, fókuszban a csontérintettség. Immunológiai Szemle 2019; XI (1): 512.

[4] Papp F. Gaucher-kór. In: Túri S. (szerk.) Tiszaparti Esték, Gyermekgyógyászati Továbbképző Előadások, 10. kötet, Szeged, 2009; pp. 103-110. 